\title{
EXPLAINING NATIONAL VARIATION IN THE USE OF MANAGEMENT CONSULTING KNOWLEDGE: A FRAMEWORK
}

\author{
Andrew Sturdy (andrew.sturdy@bristol.ac.uk) \\ \& Joe O’Mahoney (joeomahoney@gmail.com) \\ (forthcoming in Management Learning)
}

\begin{abstract}
The management literature frequently assumes that management consultancy is the predominant source of external management knowledge for organisations. However, its use is invariably confined to a few Western, developed economies. Such variation is rarely acknowledged, let alone explained. In this conceptual article, we draw on diverse literatures to explore what drives national variations in consulting usage. To achieve this, we develop a basic framework of influencing factors and apply it to the Japanese context. We conclude by explicating how our analysis has a wider application with respect to other knowledge sources in comparative studies.
\end{abstract}

Key words: Management consultancy; cross-national variation; comparative analysis; management knowledge; external knowledge sources; Japan.

\section{Introduction}

Management consultancies, organisations which specialise in providing organisational and managerial advice and 'solutions' to clients, are often assumed in management studies to be a predominant source of external knowledge. Indeed, Fincham and Clark noted back in 2002 how 'few people... will have avoided the effects of some kind of consultancy-led initiative' (2002:1). Similarly, at the conceptual level, consultancy is routinely presented as a key actor in management knowledge systems (e.g. Engwall et al, 2016; Suddaby and Greenwood, 2001). The occupation is represented as omnipresent in a variety of perspectives on organisations, professions, elites, public policy and capitalism (e.g. Thrift, 2005; Hodge and Bowman, 2006). Yet, management consultants only feature heavily in a few developed, Western countries (Source Global Research, 2016; IBIS World, 2017). 
Despite the growing literature on consulting, international variation in management consultancy usage has yet to be explored adequately. Indeed, national contexts more generally are invariably ignored (c.f. Kipping and Engwall, 2002). Theoretically, transaction-cost perspectives on consulting focus on the calculative choices that client managers make between internal and external sources of knowledge while social embeddedness approaches highlight the importance of networks (see Armbrüster, 2010). Yet, the question of which source of external knowledge is used requires an understanding of the historical, institutional and structural emergence of sources of knowledge in different environments. As Kipping and Wright (2012: 165) note:

'There is a surprising lack of research on the role of consultants in context, be it national or global. While there are studies examining the evolution of consultancy and its role within a given country, these analyses have remained largely descriptive and do little to identify, let alone compare, cross-national differences'.

This article explores what drives national variations in the use of consulting? In doing so, it problematises the predominantly Anglo-Saxon normalisation of consulting use in extant literature.

The dearth of comparative studies of consulting led us to examine studies that explain national variation in the use and adoption of management ideas, innovations and practices (hereafter 'practices'). These studies are especially relevant, given that consultants often drive the adoption of such practices, and purchasing external management advice can be seen as a management practice in itself. However, the selected studies did not focus on consulting, and its use is different from most other management practices in being intimately connected with their production and adoption. Therefore, we also included sources from a wide range of domains, including geography, sociology, policy, innovation and the professions, which specifically examine consultancy use. We subsequently integrated these insights into a basic multi-perspective framework capable of explaining why consulting use varies internationally.

The article is organised as follows: we first elaborate on the extent of national variation in consultancy usage. We then examine literature on national variations in management practices and induce drivers, such as the economy, state and culture, to explain such differences. These subsequently structure our discussion of national variations in the demand and supply of consultancy and serve as the basis for our framework, which is illustrated via the case of consultancy use in Japan. Our study is potentially important because it provides a novel 
explanation of why consulting usage varies internationally and de-naturalises the assumption that consultancy is a universal preferred source of management knowledge.

\section{International variation in the use of consultancy}

Management consultancy is often portrayed as a global phenomenon, due to the number of offices of international consulting firms situated in national and transnational business and government centres (e.g. Momani and Williams, 2017). However, this masks the extent of consulting activity. A more useful indicator is fee income, although this too is imperfect and does not necessarily equate with influence (Hodge and Bowman, 2006) ${ }^{1}$. An initial analysis of fee income regionally shows that consultancy usage is far from universal (Table 1).

Table 1. 2015 Regional share of consulting revenues (Source Global Research 2016).

\begin{tabular}{|l|l|l|}
\hline \multicolumn{1}{|c|}{ Region } & \multicolumn{1}{|c|}{$\mathbf{2 0 1 5}$ [\$bn] } & \% share \\
\hline North America & 59.1 & 47.6 \\
Europe & 36.8 & 29.6 \\
Asia Pacific & 17.0 & 13.7 \\
Central \& South America & 6.0 & 4.8 \\
Middle East & 3.0 & 2.4 \\
Africa & 2.3 & 1.9 \\
\hline
\end{tabular}

The regional concentration of usage is reflected in the fact that $78 \%$ of all management consultancy revenues come from North America (48\%) and the European Union (30\%) (Source Global Research, 2016). This partly obscures an even greater concentration at a national level, as nearly three-quarters of European consulting revenues stem from three countries (Germany, UK and France) (FEACO, 2017). Thus, along with the USA and Canada, $70 \%$ of consultancy fees worldwide are generated in only 5 nations - a much greater proportion than their share of global GDP (33\%). It is worth noting that this partly conceals the exporting of consulting, from

\footnotetext{
${ }^{1}$ Consulting industry figures vary with respect to the methodologies of the studies. Nevertheless, given that each source uses a consistent method of data collection in different countries, the figures do shed some light on variation in consulting use.
} 
the USA especially, and that the proportion has decreased from $80 \%$ in 2008 , reflecting the relatively low growth of Western consulting markets compared to that in developing countries. However, this national concentration does not simply reflect a divide between users and nonusers. Rather, as we shall see, there is considerable variation between individual nations, even among high-user countries.

Patterns of overall use at a national level both hide and are shaped by differences within countries, concerning the type of consultancy used. For example, spend on IT strategy consultants constitutes $32 \%$ of all consulting work in the UK but only $4.6 \%$ in the US (IBIS World 2017). There is also considerable variation between sectors buying consulting services. For instance, the proportion of national consulting spend in the public sector in Europe ranges from $43 \%$ in Greece to $5 \%$ in Portugal (FEACO 2017).

In short, whilst there is occasional recognition of national variation in consulting usage, 'little research has been conducted on this topic outside the major economic centres of the United States and Europe' (Wright and Kwon 2006: 356). Our review of management literature produced only a handful of articles that address the topic directly (i.e. Kipping, 2002; 2003; Kipping and Wright 2012, Mohe 2008, Pemer et al. 2014a), and even then, they tended to focus on a singular explanation (e.g. culture) or reiterated the research gap. To address this, we seek to integrate a broad range of literatures to examine what drives national variations in the use of consulting. We start by inducing five drivers of cross-national variation in management practices from a variety of studies, before exploring how these might illuminate variations in the demand for, and supply of, consulting services. We conclude by illustrating and testing our framework through a brief exploration of consulting use in Japan.

\section{The macro-context: why management practices and ideas vary internationally}

Several fields of literature have examined the factors shaping management practices nationally. There is insufficient space to address this work fully here. However, some studies seek to integrate different drivers of international differences in practices, whilst most focus on one factor. We examine the former to identify those drivers most commonly identified as influencing national variations, and then use examples of the latter to expound the main themes within each driver. The caveat to this précis is that 'countries embark on different trajectories 
depending on a complex set of variables that is very difficult to reduce to simple principles' (Guillén 2001: 15).

\section{Integrative studies}

Numerous studies across different fields integrate various drivers to understand national differences in management practices. Almond and Menendez (2014) identify three main approaches within extant literature. The first two emphasise economic/material factors and cultural/ideological differences, whilst the third concerns institutionalist accounts of the state, education, trade unions and professions. This latter approach resonates with what Jackson and Deeg (2008) term the 'comparative capitalisms' literature, which seeks to explain national (or regional) institutional configurations. Hall and Soskice's (2001) influential work that traces interactions between firms and institutions, identifies six themes through which national coordination problems are tackled: industrial relations; vocational training and education; corporate governance; inter-firm relationships; employee relationships; and a nation's 'common knowledge and culture' which helps define national norms of governance. Similarly, although with a different emphasis, Whitley's (2007) analyses of business systems highlights national differences in trade and industry associations, industrial relations, public policy, education and financial systems generating distinctive business competences for each country's organisations.

Approaches that encompass economic, cultural and institutional factors provide the basis of a broad comparative framework. However, they invariably focus on the nation, sector and relationships, rather than management practices within organisations. More relevant for our purposes is the integrative, comparative and historical approach by Guillén (1994), which focuses on the active adoption of management practices (e.g. scientific management and human relations) in different countries. Guillén sees the emergence of organisational problems in nations as deriving largely from political and economic factors (economic ideology, the competitive climate, organisational size and labour relations). Contrastingly, the demand for solutions is shaped more institutionally, consisting of a cultural dimension (elite mentalities), the support or resistance of employees, and the role of the state as a regulator and supporter of ideas. Guillén also stresses the importance of professions, in showing how they co-exist or compete for services (1994), whilst his later (2001) analysis also emphasises elite and technical education in producing different organisational forms. However, none of these integrative 
approaches concern consulting specifically. Even Guillen's work focuses on adopting ideas, not the specific source or medium of ideas. Indeed, he calls for further study into 'the relative strength and influence of different professional groups in each country’ (1994:26). ’

Overall, integrative studies of management practice adoption reveal five inter-linked and overlapping factors driving national differences. As noted already, at the most general level, these comprise economic, cultural and institutional factors. Whilst the latter vary according to purpose, context and period of history, they broadly correspond to the state, organisations and their diverse relationships and education (see Table 2).

\section{Single driver studies}

The identification of five key drivers of national variations in management practices arose primarily from our analysis of those studies that integrated different perspectives or approaches, allied with the many studies examining specific factors. In this section, we selectively draw from such research to illustrate the relevance of our framing.

Both economic and state-based explanations for national variations in management practices dominated in the early twentieth century. Concerning the former, early proponents of 'development theory' proposed a teleology by which the economic and industrial practices of nations evolved along a continuum of economic development (Dore 1990). More recently, contingency and resource-based theorists posit that certain management practices and organisational forms are varyingly successful in different economic contexts, due to GPD, economic cycle, investment and ownership patterns (Ateljević and Trivić 2016).

In contrast, 'modernization theory' in the 1950 s and 60 s emphasised the role of the state in generating different national routes to post-war reconstruction (Hood et al. 2010). Studies have hitherto examined the impact of different forms of government on management practices (Thrift, 2005) and the different levers that the state can operate. For example, they have shown how the financial powers of the state (e.g. control over capital flows) or activity in the public sector (e.g. New Public Management) affect the types of management practices adopted (Schonfield 1966). States have also been shown to influence the dominance of different groups and professions through regulation (or its absence), which supports their preferred practices (e.g. Abbott 1988). This impacts not only on who can use different forms of organisational 
expertise, but also the systems and norms of education that produce such specialists (Brint 1994) (see also 'Education' below).

In the 1980s, the concept of national culture, popularised by Hofstede (1980), was commonly depicted as a driver of various national management practices and the adoption of different management ideas (Waarts and Van Everdingen, 2005). Aside from using statistical (and static) measures of national culture, the concept has been also defined as 'unique national institutions, cultures, and histories' (Sergi and Hallin, 2011: 199). Here, culture combines elite mentalities, economic ideology, religious tropes and educational norms which shape values and practices in the workplace. Others have emphasised the regional nature of cultures, specifically the religious differences between Northern and Southern Europe or the shared cultural heritage of colonizers and their former colonies (Ibarra-Colado 2016).

Allied with economic, state-based and cultural drivers of national variation is the impact of organisations and their relationships on the nature of management practices (Battisti and Stoneman, 2010). Internally, the size and type of organization has an influence on its practices (Steers et al. 2010), as do forms of employee representation, as unions frequently resist/modify management innovations (Heyes and Rychly 2013). Externally, the concentration of organisations also has an effect. 'Clusters' of similar organisations not only share management expertise and knowledge more effectively (Crouch, 2001), but also build institutions or associations to stabilise and promote such work (OECD, 2001). Studies thus show how industry associations, centres of expertise and geographical clusters impact on firms' ability to share and adopt management practices (Cole, 1985).

Finally, and again, connected to the other drivers, research has examined the impact of national education systems on management practices. This is especially evident in historical studies (e.g. Witzel 2016) where the control and influence of education (e.g. by factory owners, religious orders or communities) is revealed as nationally diverse. More recently, literature on international variations in management stresses the colonizing effect of US higher education on management styles around the world, especially the MBA and business schools, which are linked to US style management practices (Khurana, 2010). 
Table 2 Macro-level influences on national variations in management or organisation: mapping integrative frameworks

\begin{tabular}{|c|c|c|c|c|c|c|}
\hline & Sample studies & The economy & The state & Culture and ideology & $\begin{array}{l}\text { Organisations and their } \\
\text { relationships }\end{array}$ & Education \\
\hline \multirow{3}{*}{$\begin{array}{l}\text { Integrated } \\
\text { frameworks on } \\
\text { national } \\
\text { variations in } \\
\text { management } \\
\text { and } \\
\text { organisation }\end{array}$} & $\begin{array}{l}\text { Hall and } \\
\text { Soskice (2001) }\end{array}$ & $\begin{array}{l}\text { Corporate } \\
\text { governance; } \\
\text { financial } \\
\text { investment }\end{array}$ & $\begin{array}{l}\text { State } \\
\text { intervention in } \\
\text { the economy; } \\
\text { business law; }\end{array}$ & $\begin{array}{l}\text { Common knowledge and } \\
\text { culture }\end{array}$ & $\begin{array}{l}\text { Employee relationships; } \\
\text { industrial relations; inter-firm } \\
\text { relationships; }\end{array}$ & $\begin{array}{l}\text { Vocational training } \\
\text { and education. }\end{array}$ \\
\hline & Whitley (2007) & Financial systems & Public policy & $\begin{array}{l}\text { Cultural homogeneity; } \\
\text { normalisation of governance } \\
\text { structures; }\end{array}$ & $\begin{array}{l}\text { Trade and industry } \\
\text { associations; } \\
\text { relations }\end{array}$ & Education \\
\hline & $\begin{array}{l}\text { Guillen (1994; } \\
\text { 2001) }\end{array}$ & $\begin{array}{l}\text { Economic } \\
\text { ideology, the } \\
\text { competitive } \\
\text { climate }\end{array}$ & $\begin{array}{l}\text { State regulation; } \\
\text { state structures. }\end{array}$ & $\begin{array}{l}\text { Elite mentalities; culture; } \\
\text { traditions and ideologies; }\end{array}$ & $\begin{array}{l}\text { Employee support and } \\
\text { resistance; professional } \\
\text { cooperation/competition; } \\
\text { labour relations; organisation } \\
\text { size }\end{array}$ & $\begin{array}{l}\text { Elite and technical } \\
\text { education. }\end{array}$ \\
\hline
\end{tabular}




\section{The use of management consulting}

We have induced and illustrated five themes commonly used to explain variation in international management practices. We now deploy these specifically for consultancy use. Here, we also apply a distinction between producer-driven (push) and buyer-driven (pull) linkages in the global economy (Guillen, 2001). This supply and demand approach helps to ensure an active or agentic conception of the different participants, which is not always evident in institutional accounts of national variation in practices (see critiques in Tempel and Walgenbach, 2007; Marano and Kostova, 2016). It also allows us to draw connections with wider, indirect influences on demand and supply, especially alternative or complementary purveyors of management knowledge.

\section{Pull: Demand-side drivers for international variation in the use of consultants}

\section{Economy}

Consultant demand is commonly represented in economic terms as a rational response to the complexities of globalisation, technological change, growth and regulation. Armbrüster (2010:55) uses transaction-cost economics to argue that the complexity that accompanies economic development leads to more 'one off tasks that are dissimilar to each other and dissimilar to client operations... which would explain why the consulting sector has grown' (also Ernst and Kieser 2002: 51). Indeed, more generally, economically developed countries spend much more on consulting than less 'developed' countries, as a function of both wealth (UNCTAD, 2002) and the frequent presence of larger and more complex organisations (Kipping and Armbruster, 1999). 
Yet, we cannot assume that the stage or pace of economic development wholly 'reflects the development of the management consultancy profession' (c.f. Vieira, 2003:466). Indeed, a weighting of different countries' spend on consultancy by GDP shows that even when a country's economic development is adjusted for, there remains significant differences in spending (Table 3). Whilst the high spenders on consulting are undoubtedly economically developed countries, not all developed economies are big buyers (e.g. Italy). Simultaneously, we see high usage among countries that Hall and Soskice (2001) identify as possessing contrasting forms of capitalism (e.g. Germany and the UK), which suggests that varieties of capitalism is not necessarily a key differentiator (see also Campbell and Pederson, 2014). Similarly, Momani and Williams (2017) show that 'the economic and population size of [international] cities alone do not explain the observed spatial variation in [the numbers of] offices' of multinational consulting firms (p.14, emphasis added), thereby showing economic factors do not fully explain usage differences. 
Table 3. GDP-weighted spending on consultancy in 2005

\begin{tabular}{|l|l|l|l|}
\hline Country & $\begin{array}{l}\text { Consulting } \\
\text { Revenue }^{2} \\
(\mathbf{b n})\end{array}$ & GDP $(\mathbf{b n})^{\mathbf{3}}$ & $\begin{array}{l}\text { Consulting } \\
\text { spend / GDP }\end{array}$ \\
\hline USA & 112.50 & 13094.79 & 0.86 \\
\hline UK & 19.40 & 2321.84 & 0.84 \\
\hline Germany & 18.50 & 2767.30 & 0.67 \\
\hline Japan & 20.40 & 4572.81 & 0.45 \\
\hline France & 8.40 & 2137.36 & 0.39 \\
\hline Italy & 2.60 & 1786.07 & 0.15 \\
\hline China & 2.34 & 2256.70 & 0.10 \\
\hline India & 1.49 & 834.05 & 0.18 \\
\hline South Korea & 1.64 & 844.20 & 0.19 \\
\hline
\end{tabular}

We should note that a large number of consultants are engaged on 'economic restructuring' or 'development' projects, especially with the World Bank and IMF, who use such transformations as a condition for loans (Cooke 2004; UNCTAD, 2002). However, much of this activity is hidden from national management consultancy statistics and this may partially

\footnotetext{
${ }^{2}$ Source: Datamonitor (2008)

${ }^{3}$ World Bank Figures. 2005. Available at: http://data.worldbank.org/indicator/NY.GDP.PCAP.CD?page=1
} 
inflate the apparent concentration of activity in the West, as consulting revenues in developing countries generally flow back to offices in the US or UK especially (Boussebaa et al, 2012).

\section{The state}

Another potential explanation for national variation in consulting demand relates to political governance and direct purchasing of consultancy by the state. In the UK, for example, governments increased consultancy usage in the public sector, in part due to resistance towards new knowledge and reform from the Civil Service (Saint-Martin, 2004). Demand is also fostered by government policies such as New Public Management (NPM) and Brexit (Cornish 2017), as well as more direct subsidies for consultancy use by start-ups. However, regime change and adverse publicity can lead to governments curbing public sector spending on external consulting (Pemer et al, 2014b). Governments also influence consulting demand by constraining and enabling purchasing practices by public sector organisations (Radnor and O'Mahoney, 2013). Moreover, recently, the Chinese government for example, discouraged organisations from working with US strategy consultancies (Anderlini, 2014).

More significantly, state regulation can also fuel consulting demand indirectly. For example, the growth of strategy consultants in the USA was driven by the 1933 Glass-Steagall Act, which prohibited banks from conducting bankers' surveys and led to consulting firms such as McKinsey to do so (McKenna, 2006). The financial crisis in South Korea fuelled a similar, temporary demand for consulting, as the state believed they added legitimacy to reforms in the eyes of the World Bank and IMF (Wright and Kwon, 2006). Likewise, the regulation of accounting firms has long had an impact on consulting usage as an alternative, and continues to do so.

\section{Culture and ideology}


The legitimacy of different forms, sources and intermediaries of knowledge is linked to cultural and ideological conditions, which sometimes occur nationally. For example, it is argued that the growth of US consultancies in Europe was not caused solely by increases in client complexity or environmental change, but also through the 'dominance effects' of post-war US market ideology, as well as client nation dependence for aid (Kipping 1999). However, as with the organisational level, political conditions can also have converse effects as resistance to the US origin of management ideas can reduce demand for consultants promoting them. This occurred in post-war Germany, Japan (Kipping 2002; 2003; Mohe, 2008) and even in high-use contexts such as the UK (Tisdall, 1982).

National cultural norms affect the reception of 'outside' influence, which has clear links to external consulting use. In individualist countries, such as the US, knowledge external to the organisation (if not to the USA) is often valued highly (Menon and Pfeffer, 2003) and thus using external consultants can have positive symbolic significance, including on a company's share price (Bergh and Gibbons, 2011). In more collectivist countries, external knowledge sources are often deemed less legitimate (Michailova and Hutchings, 2006) - the "not invented here' syndrome (Burcharth and Fosfuri, 2014). Similar perspectives, notably Hofstede (1980), posit that cultural variation in managers seeking to avoid uncertainty, for example, can be linked to consultancy use and the certainty it can offer (Mohe, 2008). However, it is only at the general level that culture has been viewed in this way:

'The North - South divide [in consulting expenditure] nevertheless might (also) suggest some very deep "cultural" and historical factors... between the Protestant or, to go even further back in time, Germanic part of Europe, where consultancies are much more developed, and the Catholic or Roman part where they seem to have made less inroads. (Kipping and Armbrüster 1999:38).

Given the dearth of research, this observation is intriguing for challenging purely economic and political accounts of consulting demand, but only scratches the surface. 


\section{Organisations and their relationships}

Linked to economic drivers, wealthier and larger organisations, especially those in complex sectors such as finance or telecoms, are typically the highest spenders on consultancy (Kennedy Information 2010). Thus, nations with large numbers of such firms are more likely to use consultants. Likewise, multinationals and their subsidiaries act as 'bridges' for consulting firms to establish a presence in a country, further spreading demand (Kipping, 1999). Such effects are reinforced by mimetic isomorphism, whereby clients with transnational networks are more likely to use consultants to adopt the 'best practices' of their competitors (Momani and Williams 2017), including consulting usage itself.

In addition to clients, related actors, such as clients' own professional bodies, have an effect. Indeed, management occupations, especially purchasing, significantly impact upon consultancy buying, not least in reducing fee rates (O'Mahoney et al., 2013). Yet, whilst it is established that procurement varies internationally, there has been insufficient comparative research on buying consulting services (Pemer et al, 2014a). There is also evidence that industrial relations are important, with employees and unions differentially resisting the use of management consultants in the public sector and elsewhere internationally (Saint-Martin, 2004). Similarly, others have shown that in Germany for example, where industry associations and government agencies acted as significant providers of management advice, the encroachment of consultancies was limited up to the late $20^{\text {th }}$ Century (Kipping, 2003).

\section{Education}

The national provision of business schools, and MBAs in particular, corresponds strongly with consulting usage (Momani and Malecki, 2012). Thus, in the US/UK and other countries where business schools are highly valued, strategy consultancies specifically can better exert forms 
of direct and indirect power (O'Mahoney and Sturdy, 2016). This relationship can be explained through ready supplies of recruits for consultancies, and more diffusely, via clients and consultants sharing a language or mind set and thus attributing greater legitimacy to this management knowledge (Sturdy et al, 2009). The ties between business schools, publishers/media and consultancies, in the US especially, are central to 'defining management' itself as well as enabling the dominance of a business education for elite graduates that often draws on consultancy-type problems and solutions (Engwall et al, 2016). Similarly, in countries such as Spain, where business schools developed separately from the major universities, American style management ideas took hold faster than, say, in Italy, where business education was modified through inclusion in the state university system (Puig 2008). In 1970s and 1980s Germany, the legitimacy of non-business and non-university education for managers was consistent with the prioritisation of alternative sources of management knowledge over consultants' knowledge (Engwall et al, 2016).

\section{Push: Supply-side drivers for international variation in consultant usage}

Guillén's (2001) theorising suggests that to understand international variation in demand for management ideas, we must also consider the 'push' or supply-side processes. This is especially relevant in consultancy where considerable energy and resources are expended promoting its use and where its ambiguity in terms of content and outcomes, means that these activities are likely to be relied upon (Karantinou and Hogg, 2001).

\section{The economy}

National economic development is loosely related to fees consultants charge and, thus, firms' incomes in different countries (Source Global Research 2016). Fees vary significantly, according to client budgets and standards of living, with senior consultants charging over 
$£ 2000$ a day in the UK and around $£ 300$ in India (O’Mahoney and Markham 2013). This translates into higher salaries for consultants in developed countries, but also a 'pull' of top talent from subsidiaries in developing countries to global and regional head-offices, where higher rates are charged and higher salaries paid (Boussebaa et al., 2012). This phenomenon therefore, can again, result in a slight overstatement of the geographical concentration of consultancy activity by fee income statistics alone.

The state

As already noted, states affect the supply of consultancies through variations in their (lack of) regulation of the industry and related activities, their promotion of competitors and their openness to influence by consultancies. Concerning regulation, (financial) barriers to entry for consultants are traditionally low, and professional status is neither compulsory nor difficult to achieve in most countries (Momani and Williams, 2017). However, there is some variation here, both temporally and geographically. Historically, compulsory professionalisation was an aspiration in the early development of consulting as firms sought to build credibility (McKenna, 2006). More recently, Canada, Austria and Germany have sought to reintroduce compulsory (state enforced) professionalisation, even though Austria is the only (partially) successful case (Groß and Kieser, 2006). Whilst such restrictions may result in fewer consultants entering the profession, recent research indicates that licencing of professional occupations results in higher fees (Kleiner and Vorotnikov, 2017).

Secondly, states often promote institutions viewed as competitors to the consulting industry. In 1980s South Korea, for example, the government 'prohibited the establishment of local offices by foreign service providers', instead encouraging local businesses to partner with overseas firms 'taking advantage of foreign technology and managerial know-how, which they then absorbed and internalized' (Wright and Kwon 2006: 360). Thirdly, some governments buy more consultancy services than they otherwise would because consultancies have 
previously shaped agendas and framed challenges. O'Mahoney and Sturdy (2016) show that these activities include placing consultants in senior government roles; providing 'free' training and advice which shapes policy discussions; and, of course, political funding and lobbying (see also Hodge and Bowman 2006:14).

\section{Culture and ideology}

There is limited research on how culture and ideology influence the supply of consulting expertise globally. It is instructive to examine the emergence and evolution of consulting in its different forms in relation to cultural contexts and connections. For example, the normative origins of 'professional' consultancy consciously mimicked occupations, such as law, accounting and the academy, to secure legitimacy (David et al 2013). More recently, management consultancies also draw on other professional cultural tropes and technocracy, along with emerging logics around American neo-liberalism, with consultants presented as capitalism's 'missionaries' or 'commissars' (Thrift, 2005). This is reflected in consultancy texts and active strategies which seek to exert influence over buyers in more direct ways (Momani, 2017). Consultancy is both a condition and consequence of prevailing ideology, in that it operates as both a servant of power and active agent or neo-imperialist, even if resistance is also evident (Hurl, 2018).

\section{Organisations and their relationships}

Consultancies, and their associated networks, are integral to creating international differences in the supply of management advice. First, the partnership structure of many consulting firms tends to generate extreme internal competition between global/regional headquarters and subsidiaries, whereby the former generate profits derived from staff in the latter (Boussebaa et al, 2012). Second, the indirect sales approach undertaken by many consultancies relies upon 
an historical embeddedness with a country's elite institutions- a condition that is only met in the US and a few other Western European countries (Saint-Martin, 2004). Like the state, such relationships allow firms to influence client agendas and frame issues as ones that consultancies can best tackle (David et al, 2013; Sturdy, 2018).

It is similar story with respect to the powerful alumni networks upon which consultancies draw (McDonald, 2013). The 'up or out' model pursued by some leading consultancies produces a cadre of able, elite and ambitious alumni in client firms that generally become more senior over time (Sturdy and Wright 2008). Thus, countries where consultancies are well established for decades have greater opportunities for sales, and other advantages stemming from the network. That is to say, variations in international consultancy usage are open to feedback or 'contagion' effects noted in innovation studies, whereby demand can feed itself through users' exposure to other actors' knowledge (Van den Bulte and Lilien, 2001). This is especially important given the reliance consulting has on 'networked reputation' (Armbruster, 2010)

Finally, consultancy exists in competition with a wider external market, including business schools/academics, management gurus, public research institutes, industry associations, thinktanks and training and other occupations (Foss et al 2013). As mentioned earlier, in Germany, alternative knowledge suppliers provided serious competition for consultancies (Faust and Schneider, 2014). However, competitive relations can also be cooperative. Tether and Tajar (2008) found that external consultants complement internal innovation activities, and other external sources of knowledge. Similarly, Kipping (2002; 2003) showed how, in the 1970s, German industry organisations which were once alternatives to consulting came to provide a mediating role for them, even actively recommending their use.

\section{Education}


The concentration of consulting supply also corresponds to the availability and preferences of potential recruits and their education. Given that consulting, in the large firms at least, is historically associated with young MBA graduates (David et al, 2013), the question of labour supply is associated with the location and status of business schools. In the US/UK context, business degrees and MBAs are dominant, and a natural precursor to consultancy careers. While some change is evident (Engwall et al, 2016), the continuing preference of large consulting firms for elite MBA graduates limits labour supply to a small number of countries or cities (Wood, 2003). National differences also influence the choices of 'good' graduates. In the US/UK, consultancies have long ranked high as a preferred graduate employer, whilst in France, the Grandes Ecoles prioritise engineering and civil service careers (O’Mahoney and Markham 2013).

\section{Summary}

Following our identification of five themes commonly used to understand international variation in management practices, we subsequently used diverse literatures to explain the varying demand and supply of consulting services globally. These insights helped us generate general observations or specific hypotheses concerning the impact of push and pull drivers on consultancy usage (summarised in Table 4). However, three caveats must be emphasised. First, these hypotheses reflect underlying tendencies that may sometimes cancel each-other out and, therefore, may not have clear empirical manifestations. Second, such tendencies are context dependent (such as economic recessions or negative publicity) and should be understood as having an effect only ceteris paribus. Finally, the hypotheses should not only be read as unidirectional (for example, more consultancies cause more MBA students). 
Table 4. Hypothetical 'Push / Pull' drivers for national variations in management consulting use

\begin{tabular}{|c|c|c|}
\hline & Influence on pull factors & Influence on push factors \\
\hline Economy & $\begin{array}{l}\text { 1. Countries with many large and/or profitable businesses are able to } \\
\text { afford more consulting services. } \\
\text { 2. Countries hosting more globalised, complex and/or innovative } \\
\text { organisations will use greater levels of external expertise (see also 19). } \\
\text { 3. Countries initiating (or subject to) complex restructuring (e.g. } \\
\text { privatisation, post-war reconstruction, deregulation) will require } \\
\text { greater levels of external expertise (see also 7). } \\
\text { 4. Countries with long-term investment strategies will focus on } \\
\text { developing internal assets rather than outsourcing. }\end{array}$ & $\begin{array}{l}\text { 5. The higher the average fee rate, the greater revenue per } \\
\text { consultant is expected. }\end{array}$ \\
\hline State & $\begin{array}{l}\text { 6. States initiating radical public sector reforms (e.g. New Public } \\
\text { Management) are more likely to use consultants in public sector. }\end{array}$ & $\begin{array}{l}\text { 9. Greater barriers to entering into consulting profession will } \\
\text { result in fewer consultants, but potentially higher fees (see also }\end{array}$ \\
\hline
\end{tabular}




\begin{tabular}{|c|c|c|}
\hline & $\begin{array}{l}\text { 7. States facing or initiating radical societal changes (e.g. Brexit; } \\
\text { financial crises) are more likely to use consultants in central } \\
\text { government (and increase consulting use in wider economy - see also } \\
\text { 3). } \\
\text { 8. Governments with coherent service sector purchasing strategies will } \\
\text { pay lower consulting rates than those without. }\end{array}$ & $\begin{array}{l}\text { 30). Barriers to competing organisations (e.g. banks, auditors) } \\
\text { will have the opposite effect. } \\
\text { 10. Greater competition between consultancies and state- } \\
\text { sponsored knowledge-sharing institutions is likely to result in } \\
\text { smaller consulting market (see also 22). } \\
\text { 11. Greater openness of the state to influence from consultancies } \\
\text { (e.g. on government boards), the more public sector consulting } \\
\text { is expected. }\end{array}$ \\
\hline $\begin{array}{ll}\text { Culture } & \text { and } \\
\text { ideology } & \end{array}$ & $\begin{array}{l}\text { 12. Countries with strong (positive) cultural and political engagement with } \\
\text { the US are more likely to use management consultants. } \\
\text { 13. Countries with high levels of individualism more likely to use } \\
\text { management consultants than countries with high levels of } \\
\text { collectivism. } \\
\text { 14. Countries with strong neo-liberal ideologies are more likely to use } \\
\text { management consultants. }\end{array}$ & $\begin{array}{l}\text { 15. The greater the institutional embeddedness of consultancies in } \\
\text { a nation, the greater likelihood of higher revenues (see also 26). } \\
\text { 16. Higher involvement in development and overseas work will } \\
\text { result in greater revenues for consulting firms. }\end{array}$ \\
\hline
\end{tabular}




\begin{tabular}{|c|c|c|}
\hline $\begin{array}{l}\text { Organisations } \\
\text { and their } \\
\text { relationships }\end{array}$ & $\begin{array}{l}\text { 17. Countries with wealthier organisations and sectors will spend more on } \\
\text { consultants (see also 1). } \\
\text { 18. Countries with organisations facing unique, complex challenges are } \\
\text { more likely to use consultants (see also 2). } \\
\text { 19. Countries with more clients that are subsidiaries of Western multi- } \\
\text { nationals are more likely to use consultants, due to 'bridging' effects } \\
\text { (see also 2). } \\
\text { 20. Countries with more organisations with centralised and developed } \\
\text { purchasing departments will pay lower consulting rates than those } \\
\text { without (see also 8). } \\
\text { 21. Countries with lower levels of unionisation will spend more on } \\
\text { management consultants. } \\
\text { 22. Countries with more industry associations, government knowledge- } \\
\text { exchange programmes, and intra-company exchanges will spend less }\end{array}$ & $\begin{array}{l}\text { 23. Countries hosting consultancy head-offices for consultants will } \\
\text { tend towards higher revenues. } \\
\text { 24. The greater each country's use of overseas subsidiary } \\
\text { consultants, the greater revenue to be expected (e.g. PWC UK } \\
\text { using PWC India consultants). } \\
\text { 25. Institutionalised involvement of consultancies in agenda setting } \\
\text { institutions, such as think-tanks, conferences and client boards } \\
\text { results in greater consulting use. } \\
\text { 26. Greater presence of consulting firms and/or their promotion } \\
\text { activities and established networks with potential clients will } \\
\text { lead to greater use (due to contagion effects). }\end{array}$ \\
\hline
\end{tabular}




\begin{tabular}{|c|c|c|c|}
\hline & $\begin{array}{l}\text { on consultancy when such bodies compete directly with (c.f. broker) } \\
\text { consulting firms. }\end{array}$ & & \\
\hline Education & $\begin{array}{l}\text { 27. Countries with US-style business schools and large MBA programmes } \\
\text { are more likely to spend more on consultants. }\end{array}$ & & $\begin{array}{l}\text { Greater numbers of MBA students and business schools likely } \\
\text { to be associated with more national employment of consultants, } \\
\text { and greater revenues. } \\
\text { Where consultancies have a strong reputation with graduates, } \\
\text { greater usage is expected. } \\
\text { Compulsory professionalisation may result in fewer } \\
\text { consultants, but higher fees. }\end{array}$ \\
\hline
\end{tabular}




\section{An illustration: Japanese use of management consultants}

Having developed a basic framework and articulated it at a general level in terms of hypothetical claims, we now illustrate its utility by applying it to consultancy use in Japan. We reiterate that the case is not meant to 'test' the hypotheses, but to illustrate how they might work and interact in practice (numbered hypotheses in Table 4 are referred to in square brackets in the text below). We chose Japan, not only because there is some, albeit limited, data about the country's consultancy usage, but because it is unusual both economically and geographically, and is changing. For a developed, mature economy, with thriving high-tech, banking and media sectors, it spends approximately half of the UK or US on consultants when adjusted for GDP (Table 3). Yet, in the context of Asia, Japan is a comparatively big spender, \$25bn in 2015, compared to \$4bn in China (Source Global Research, 2016). Japan also has an unusual weighting for consulting disciplines, with a greater proportion of fees dedicated to operations management and HRM, and relatively little on corporate strategy (Table 5).

Table 5. Management Consultancy Sector Proportions 2015 (MarketLine, 2015)

\begin{tabular}{|l|l|l|l|l|l|}
\hline & $\begin{array}{l}\text { Operations } \\
\text { Management }\end{array}$ & $\begin{array}{l}\text { Information } \\
\text { Technology }\end{array}$ & $\begin{array}{l}\text { Corporate } \\
\text { Strategy }\end{array}$ & HRM & Other \\
\hline Germany & $35.0 \%$ & $29.9 \%$ & $16.7 \%$ & $7.4 \%$ & $11.0 \%$ \\
\hline UK & $46.0 \%$ & $20.6 \%$ & $11.0 \%$ & $10.3 \%$ & $12.1 \%$ \\
\hline France & $65.7 \%$ & $9.8 \%$ & $9.0 \%$ & $3.5 \%$ & $12.0 \%$ \\
\hline Japan & $28.6 \%$ & $29.4 \%$ & $5.4 \%$ & $25.0 \%$ & $11.6 \%$ \\
\hline
\end{tabular}

\section{Economy}

Japan has a GDP of $\$ 5.4 \mathrm{tn}$ ( $4^{\text {th }}$ globally) and a GDP per capita of $\$ 47,082$ (comparable to the UK and France) [1]. In the IMF ranking of financial liberalisation, a loose measure of neoliberal policies, Japan has a middle ranking of 0.86 (similar to Norway), well below most of Western Europe and the USA (1.00) (Abiad et al. 2008). Hence, Japan is characterised as a 
model of 'co-operative capitalism' rather than the US/UK form of neo-liberalism (Schaede 2000) [14].

Japan is also home to some of the world's largest and advanced automotive, electronics and telecoms multinationals, is a strong exporter of manufactured goods, and is ranked as one of the most innovative countries $[1 ; 2 ; 18]$. Thus, Japanese industry not only faces complexities that require external management advice, it is able to afford the rates of top consultancies (typically 15\% lower in Japan than W. Europe or the USA [19]) (Kimble 2015). Moreover, Japan has faced significant economic reforms, both in the post-war period and the post-2012 structural reforms of Shinzō Abe [3]. Conversely, some sectors which traditionally spend more on consulting, such as banking and finance, are proportionally smaller in Japan than the US/UK [17].

Financing, long-term servicing of debt by credit banks and government bonds (rather than the stock market) meant that large Japanese companies tended towards long-term strategic investments, where company assets - including management - are invested in rather than outsourced (Hata et al. 2007) [4]. In entrepreneurship activities too, the majority of venture capital is provided by banks and insurance companies through loans, rather than individuals in the US (Sako 2007). The former arrangement is less likely to involve consultants being 'foisted' on entrepreneurs by fund / stock owners.

\section{The state}

The post-war Japanese state rebuilt and improved domestic industry, supporting many institutions still in evidence today [3]. As 'higher academic institutions were neither willing, nor equipped, to deal with (US management knowledge) by way of graduate schools' (Nishizawa 1998: 88), the Japanese government worked with large businesses to develop a number of institutions to ensure 'best practice' management techniques were disseminated [10; 22]. These included productivity and management development institutes, which often substituted for consultancies in providing management training and advice on manufacturing improvements. Indeed, the US expertise that rebuilt and modernised Japanese manufacturing in the 1950s came not from management consultants, but from government supported institutions such as the Japan Human Relations Association (Kuokkanen and Seeck, 2009). Whilst the state's role has changed, it still provides long-term financing for industry 
investment, such as 'corporate revival funds,' provided in the UK by venture capital or stock market investors that often insist on management consultants [4].

The Japanese state is a low-user of management consultants (Shigeki 2003), perhaps because its attempts at public sector modernisation were limited, and because it focused on cost-cutting [6; 11]. Radical changes made by the state in the 1990s due to low growth primarily focused on macro-economic levers affecting the private sector, rather than major internal changes (Masaharu 2003) [6]. Thus, although all the major consulting firms have a Japanese presence, their respective Japanese websites reveal little public sector engagement, and virtually no central government work. PWC Japan, for example, lists several links for its services, but the "Government and public sector" link is dead (compared to dozens of cases, services and reports for its UK site $)^{4}[11]$. In terms of regulating the consulting market, the Japanese government has a similar approach to the UK/US with no compulsory registration or examination for consultants $[9 ; 30]$.

\section{Culture and ideology}

The characterisation of Japan as a highly collectivist, risk-adverse and long-term orientated society is borne out in much quantitative (House et al. 2004) and qualitative research (Yoda and Harootunian, 2006). The strong collectivist bonds in Japanese society are mirrored in some large companies through strong group cohesion (Miroshnik and Basu, 2014), meaning that outsiders, especially foreigners (gaijin), are often distrusted (Kashima and Kashima, 2003) [13]. Indeed, Kipping (2002) argued post-war consultancy was perceived as a foreign, US invention which struggled to establish itself [12]. However, we should not overplay the strength of insularity in Japan, as its industrialisation was driven through adopting foreign models, albeit not consulting (see Westney, 1986). Collectivism also translates into a form of consensual decision-making, ringiseido, which is supported by frequent reporting, touching-base and discussion, known as hourensou (Samovar et al., 2011). It would traditionally have been anathema for companies to seek outsiders' advice on strategic decisions, which perhaps helps explain its continuing low spending on strategy consulting (see Table 5) [12; 13].

\footnotetext{
${ }^{4}$ https://www.pwc.com/jp/en/industries.html Accessed 27.02.18.
} 


\section{Organisations and their relationships}

A notable feature of the Japanese economy is that, until recently, it was comparatively closed to Western influence (Jackson and Moerke, 2005). Levels of foreign investment are much lower than Western countries, whilst a 'liability of foreignness' means it is difficult for multinationals to acquire Japanese firms (Morgan 2012: 23) [4; 19]. The inwardness of Japanese industry was long reinforced by the keiretsu system of firms, connected through sharing financial, knowledge and governance arrangements (Learmount 2002), which might mitigate the aforesaid 'contagion' or 'bridging' effects of foreign multinationals [19; 26]. Such complexities encourage intra-company exchanges of management expertise without relying on outside sources, such as consultants [22]. Yet, these arrangements shifted post-1990s, Kipping (2002) argues, as increased Japanese openness to Western investment and the challenges of shifting from seniority to performance-based careers, increased consultancy usage, especially HR consulting [19].

Japanese firms are then, more likely to turn to knowledge institutions shared with the government, universities, their supply chains and keiretsu, and even trusted competitors, than (especially Western) consultancies (Kipping, 2002) [22]. This internal focus is mirrored by HRM strategies of large Japanese firms that stress 'a long-term relationship between the corporation and its employees... the importance of firm-specific skills....and in-house training' (Abe and Hoshi 2007:259) [4]. For example, parent companies frequently undertake employee transfers (shukko) to suppliers to improve the quality or cost of their parts (Nonaka and Nishiguchi, 2001). Consequently, when facing a shortage of management expertise, firms are more likely to recruit for, or train, internal resources than look externally (Ichniowski and Shaw, 1999). Indeed, Japanese companies spend 3\% of their turnover on training (primarily in-house), six times that of the UK (Storey 2014). It is this greater spend on personnel activities, allied with the expertise required to manage this effort, that we argue, paradoxically, contributes to the relatively high Japanese spend on HR consulting (Table 5).

Consulting firms are new to Japan, and there are few 'home grown' consultancies; indeed, none of the biggest 50 firms have headquarters in Japan $[15 ; 25 ; 26]$. The few that do exist, such as Fujitsu Consulting and Toyota Production Consulting, are generally the internal consulting teams of Japanese industry that sought to increase revenues by offering their services first to 
their supply chains and subsequently to external clients. Although all major overseas consultancies now have offices in Japan, their focus is less on offering operational improvements and more on helping Japanese companies internationalise or introduce new technology (Table 5).

Although Japan has 22\% union membership (roughly the OECD average), its unions tend to have more harmonious and co-operative relationships with employers (OECD 2014). Whilst consultants are rarely initiators of shop-floor change in Japan, this is not due to union intransigence towards consultants, but, rather, down to the preferences of Japanese managers for internal advice [21].

\section{Education}

Locke and Spender (2011) argue that highly networked post-war Japanese corporations prized process over content-based management. This emphasises interpersonal relationships, consensus building, tacit learning and company specific knowledge, rather than US-style models and steps of management and change. Consequently, 'US business school education.... was irrelevant' in Japan (ibid. p. 32) [27; 28]. Whilst major Japanese universities have now opened business schools, relatively few home students attend these because Japanese corporations regard graduate students as similarly qualified to undergraduate students (Yonezawa 2011). Hence, MBA programmes are often dominated by overseas students, and business education, when it happens, invariably focuses on technical issues rather than strategy (Yonezawa 2011). Japanese caution towards US-style management education (and knowledge) is shared by top graduates who tend to choose keiretsu organisations over consultancies for employment (Kipping, 2002) [29].

Before concluding on our analysis, it is worth reflecting on the conceptual insights gained from the Japanese case. We sought to illustrate how the identified drivers might operate and interact in practice. In this regard, there appears to be a balance of drivers for greater consultant use (for example, being a highly developed economy with large, complex industries and few barriers to entering the profession) and against their use (being a relatively insular, communitarian culture with low levels of formal management education, few institutionalised relationships with consultants, and several state and industry sponsored alternatives). This balance fits Japan's outlier position regarding consulting use in advanced economies. Below, 
we consider the contribution of the case, but also of our framework more generally, before pointing to future research opportunities.

\section{Conclusion}

Across many disciplines, external management consultancy usage is represented not only as highly significant, but also often as universal. Yet, as we have seen, the majority of consultancy usage is concentrated within a few Western developed economies, and explanations for such variation are limited. Transaction cost or social embeddedness approaches to the decisionmaking process of buyers in general (e.g. Armbrüster, 2010) invariably fail to distinguish between consultancy and other sources of external management advice and overlook the wider national social and political contexts of such decisions (Kipping and Wright 2012; Mohe 2008).

To explain national variations in consultancy usage, we induced five drivers (the economy; the state; culture and ideology; organisations and their relationships and; education) deriving from international comparative analyses of management practices. We then introduced demand- and supply-side perspectives (Guillén, 2001) to show how national variations in consulting use are driven by these factors, developing both specific and general hypotheses. We applied this framework briefly to Japan where the drivers and several hypotheses were confirmed as expedient and collectively exhaustive for our purposes. However, this raised further questions and possibilities for conceptual development.

Our analysis is important in three respects. Firstly, the management knowledge and consulting field has stressed the need for such an account (e.g. Kipping and Wright; 2012; Mohe 2008). Such calls recognise the value of understanding both knowledge and consulting use in context, and the dynamic processes involved. Secondly, the explanatory framework developed here is potentially useful for understanding variation in other sources of management knowledge, both internal and external. Indeed, there is, as yet, no research examining variations in adoption of management ideas cross-nationally in conjunction with the role of different actors. Thus, our research expands upon survey-based studies of general innovation (Battisti and Stoneman, 2010), and addresses the gap in research explaining international variation in usage of different channels for adoption. It could subsequently be applied to industry associations, business schools, think-tanks, management gurus and training. Finally, by tracing national variation and indeed, concentration in consulting use, we de-naturalise the (primarily US and northern 
European) assumption in management and organisation studies that consultancy is the 'go to' source of external management expertise.

The paper has some limitations and areas for development. First, space limited us to one casestudy. It would be instructive to undertake a comparative analysis to evaluate the drivers and their interrelationships. One could explore comparatively extreme contexts, such as where consulting use is low (e.g. Faust and Schneider, 2014), declining (e.g. Wright and Kwon, 2006) or surprising (Tempel and Walgenbach 2007). Similarly, the framework could be utilised to examine knowledge sources or national 'knowledge regimes' which are structured differently to those in business (e.g. medical, technical, academic, economic policy) (see Campbell and Pedersen, 2014). Second, although our case was short and the analysis failed to unearth any significant omissions from the framework, we found five hypotheses which we had insufficient data to apply $[7 ; 8 ; 16 ; 20 ; 24]$. Furthermore, an extensive study could obtain data to examine the effects of these and other drivers and weight them all by importance, identifying interdependencies and dynamic relations (see Marano and Kostova, 2016). Third, the paper focused on national variations. Yet, several of the enablers and constraints covered, including the law, operate at a trans- or inter-national level (Seabroke, 2014). Indeed, the EU is the originator of much of the legislation which forces public sector organisations to undertake competitive tendering for consultancy. Future studies might examine the inter-relationships between regional, national and transnational levels. Similarly, we underscored some of the dynamics within nations that can explain further the national picture, such as industrial sector profiles and organisation size. These areas of future research would both aid understanding of consultancy and its position relative to other sources of management knowledge, which, in turn, would reveal policy options in the field of management and organisational learning.

\section{References}

Abbott A (1988) The system of professions. Chicago: University of Chicago Press.

Abe M and Hoshi T (2007) Corporate finance and human resource management in Japan. In: Aoki M, Jackson G and Miyajima H (eds) Corporate governance in Japan Institutional change and organizational diversity. Oxford: Oxford University Press, pp.257-281.

Abiad A, Detragiache E and Tressel T (2008) A new database of financial reforms. IMF Working Paper, Washington, DC, December 2008. 
Almond P and Gonzalez MC (2014) Cross-national comparative human resource management and the ideational sphere: a critical review. The International Journal of Human Resource Management 25(18): 2591-2607.

Anderlini J. (2014) China clamps down on US consulting groups. Financial Times. London. 25 May.

Armbrüster T (2006) The economics and sociology of management consulting. Cambridge: Cambridge University Press.

Ateljević J and Trivić J (2016) Economic development and entrepreneurship in transition economies. Switzerlan: Springer, Cham Publisher.

Battisti G and Stoneman P (2010) How innovative are UK firms? Evidence from the fourth UK community innovation survey on synergies between technological and organizational innovations. British Journal of Management 21(1): 187-206.

Bergh D and Gibbons P (2011) The stock market reaction to the hiring of management consultants A signalling theory approach. Journal of Management Studies 48(3): 544-567.

Boussebaa M, Morgan G and Sturdy A (2012) Constructing global firms? National, transnational and neocolonial effects in international management consultancies. Organization Studies 33(4): 465-486.

Brint S (1994) In an age of experts. Princeton: PUP.

Burcharth A and Fosfuri A (2014) Not invented here: how institutionalized socialization practices affect the formation of negative attitudes toward external knowledge. Industrial and Corporate Change 24(2): 281-305.

Campbell JL and Pedersen OK (2014) The national origins of policy ideas: Knowledge regimes in the United States, France, Germany, and Denmark. Princeton: Princeton University Press. Cole RE (1985) The macropolitics of organizational change: A comparative analysis of the spread of small-group activities. Administrative Science Quarterly 30(4): 560-585.

Cooke B (2004) The managing of the (third) world. Organization 11(5): 603-629.

Cornish, C. (2017) Management consultants make hay out of Brexit uncertainty. Financial Times. March 13th.

Crouch C, Gales PL ,Trigilia C and Voelzkow H (2001) Local production systems in Europe: Rise or demise?.OUP Catalogue: Oxford University Press.

Datamonitor (2008) Global management \& marketing consultancy. Datamonitor Management Consulting Reports. Sydney. 
David RJ, Sine WD and Haveman HA (2013) Seizing opportunity in emerging fields: How institutional entrepreneurs legitimated the professional form of management consulting. Organization Science 24(2): 356-377.

Dore RP (1990) British Factory Japanese Factory The Origins of National Diversity in Industrial Relations, With a New Afterword. Berkerley: University of California Press.

Engwall L and Kipping M (2006) Management education, media and consulting and the creation of European management practice. Innovation The European Journal of Social Science Research 19(1): 95-106.

Engwall L, Kipping M and Usdiken B (2016) Defining management: Business schools, consultants, media. London: Routledge.

Ernst B and Kieser A (2002) In search of explanations for the consulting explosion. In: SahlinAndersson K and Engwall L (eds) The expansion of management knowledge. Stanford: Stanford University Press, pp.47-73.

Faust M and Schneider K (2014) Functional Equivalents to External Consulting-a Case Study on a Reluctant German Corporation. Globale Managementberatung. Berlin: Rainer Hampp Verlag, pp. 155-192.

FEACO (2017) European management consultancy market 2015-16.Available at : www.FEACO.org.

Fincham R and Clark T (2002) Introduction The emergence of critical perspectives on consulting. In: Clark T and Fincham R (eds) Critical Consulting. Oxford: Blackwell, pp. 1-18. Foss NJ, Lyngsie J and Zahra SA (2013) The role of external knowledge sources and organizational design in the process of opportunity exploitation. Strategic Management Journal 34(12): 1453-1471.

Groß C and Kieser A (2006) Are consultants moving towards professionalization? In: Professional service firms. Emerald Group Publishing Limited, pp. 69-100.

Guillén MF (2006) The Taylorized beauty of the mechanical: Scientific management and the rise of modernist architecture. Princeton: Princeton University Press.

Guillén MF (1994) Models of management. Chicago: University of Chicago Press.

Hall PA and Soskice DW (2001) Varieties of capitalism: The institutional foundations of comparative advantage. Oxford: Oxford University Press.

Hata N, Ando H and Ishii Y (2007) Venture capital and its governance. In: Aoki M, Jackson G and Miyajima H (Eds) Corporate governance in Japan. Oxford: Oxford University Press, 151179. 
Heyes J and Rychly L (2013) Labour administration in uncertain times. London: Edward Elgar Publishing.

Hodge G and Bowman D (2006) The consultocracy: The business of reforming government. Privatization and market development: Global movements in public policy ideas. Cheltenham: Edward Elgar, pp. 97-126.

Hofstede G (1980) Culture's consequences: International differences in work-related values. New York: Sage Publications.

Hood C, Margetts H and Perri (2010) The drive to modernize. In: Hood C, Margetts H and Perri (eds) Paradoxes of modernization. Oxford: Oxford University press, pp.3-16.

House RJ, Hanges PJ and Javidan M Et al. (2004) Culture, leadership, and organizations: The GLOBE study of 62 societies. London: Sage Publications.

Hurl C (2018) Operationalizing austerity: the role of transnational professional services firms in local government restructuring. Innovation The European Journal of Social Science Research 31(1): 55-67.

Ibarra-Colado E (2016) Organization studies and epistemic coloniality in Latin America thinking otherness from the margins. Organization. 13(4): 463-488.

IBIS World (2017) Global management consultants. January.

Ichniowski C and Shaw K (1999) The effects of human resource management systems on economic performance: An international comparison of US and Japanese plants. Management Science 45(5): 704-721.

Jackson G and Moerke A (2005) Continuity and change in corporate governance comparing Germany and Japan. Corporate Governance An International Review 13(3): 351-361.

Karantinou KM and Hogg MK (2001) Exploring relationship management in professional services a study of management consultancy. Journal of Marketing Management 17(3-4): 263286.

Kashima Y and Kashima ES (2003) Individualism, GNP, climate, and pronoun drop is individualism determined by affluence and climate, or does language use play a role? Journal of Cross-Cultural Psychology 34(1): 125-134.

Kennedy Information (2010) Global and US Trends in management consulting. Kennedy Information, New York.

Khurana R (2010) From higher aims to hired hands: The social transformation of American business schools and the unfulfilled promise of management as a profession. Princetion: Princeton University Press. 
Kimble (2015) 2015 Global professional services report. Service Performance Insight. October.

Kipping M (1999) American management consulting companies in Western Europe, 1920 to 1990: Products, reputation, and relationships. Business History Review 73(2): 190-220.

Kipping M (2002) Why management consulting developed so late in Japan and does it matter? Hitotsubashi Business Review 50(2): 6-21.

Kipping M (2003) 'Importing' American ideas to West Germany, 1940s to 1970s: from associations to private consultancies. In: Kudo A, Kipping M and Schröter H (eds) German and Japanese business in the boom years. London and New York: Routledge, pp. 30-53.

Kipping M and Engwall L (Eds) (2002) Management consulting: Emergence and dynamics of a knowledge industry. Oxford: Oxford University Press.

Kipping M and Armbrüster T (1999) The consultancy field in Western Europe. CEMP Report: The University of Reading.

Kipping M and Wright C (2012) Consultants in context: global dominance, societal effect and the capitalist system. In: Clark T and Kipping M (Eds) The Oxford Handbook of Management Consultancy. Oxford: Oxford University Press, pp.165-185.

Kleiner MM and Vorotnikov E (2017) Analyzing occupational licensing among the states. Journal of Regulatory Economics 52(2): 132-158.

Kuokkanen A and Seeck H (2009) Comparing the adoption and legacy of the human relations school in Finland and Japan. Asia-Pacific Economic and Business History Conference. London: LES Online Research.

Learmount S (2002) Corporate governance: what can be learned from Japan? Oxford: Oxford University Press.

Locke RR and Spender JC (2011) Confronting managerialism How the business elite and their schools threw our lives out of balance. London: Zed Books Ltd.

Marano V and Kostova T (2016) Unpacking the institutional complexity in adoption of CSR practices in multinational enterprises. Journal of Management Studies 53(1): 28-54.

MarketLine (2015) Industry profile: global management and marketing consultancy. January: 0199-0424. www.market-line.com.

Masaharu H (2003) Japanese public administration and its adaptation to New Public Management. Ritsumeikan Law Review, Ritsumeikan University, Ristumeikan.

McDonald D (2013) The firm: the story of McKinsey and its secret influence on American business. New York: Simon and Schuster Paperbacks. 
McKenna CD (2006) The world's newest profession management consulting in the twentieth century. Cambridge: Cambridge University Press.

Menon T and Pfeffer J (2003) Valuing internal vs. external knowledge: Explaining the preference for outsiders. Management Science 49(4): 497-513.

Michailova S and Hutchings K (2006) National cultural influences on knowledge sharing: A comparison of China and Russia. Journal of Management Studies 43(3): 383-405.

Miroshnik V and Basu D (2014) Corporate culture in multinational companies: A Japanese perspective. UK: Macmillan Publishers.

Mohe M (2008) Bridging the cultural gap in management consulting research. International Journal of Cross Cultural Management 8(1): 41-57.

Momani B and Malecki M (2012) The global reach of management consulting firms. Occasional paper. Canada: University of Waterloo.

Momani B (2017) Professional management consultants in transnational governance. In:

Seabroke L and Henriksen LF (Eds) Professional networks in transnational governance. Cambridge: Cambridge University Press, pp.245-265.

Momani B and Williams K (2017) The geography of multinational management consulting firms: mapping global expansion in developing markets. Paper presented at the American Association of Geographers Conference, Boston, April 2018.

Morgan G (2012) International business, multinationals and national business systems. In: Wood G and Demirbag M Handbook of institutional approaches to international business. Edward Elgar: Cheltenham, pp. 18-41.

Nishizawa T (1998) The development of managerial human resources in Japan. In: Engwall L and Zamagni V (eds) Management education in historical perspective. Manchester: Manchester University Press, pp. 83-94.

Nonaka I and Nishiguchi T (2001) Knowledge emergence: social, technical, and evolutionary dimensions of knowledge creation. New York: Oxford University Press.

O’Mahoney J and Markham C (2013) Management consulting. London: Oxford University Press.

O'Mahoney J and Sturdy A (2016) Power and the diffusion of management ideas: The case of McKinsey \& Co. Management Learning 47(3): 247-265.

O'Mahoney J, Heusinkveld S and Wright C (2013) Commodifying the commodifiers: the impact of procurement on management knowledge. Journal of Management Studies 50(2): 204-235. 
OECD (2001) Innovative networks co-operation in national innovation systems. OECD Publishing: Paris.

OECD (2014) Annual labour force statistics. OECD Publishing: Paris.

Pemer F, Sieweke J and Werr A Et al. (2014) The cultural embeddedness of professional service purchasing. Journal of Purchasing and Supply Management 20(4): 273-285.

Pemer F, Borjeson L and Werr A (2014) Government agencies use of management consulting services in Sweden. In: Novak Druce conference paper, Washington, 2014.

Puig N (2008) Business education in Spain. The Business History Review 82(2): 348-353.

Radnor Z and O'Mahoney J (2013) The role of management consultancy in implementing operations management in the public sector. International Journal of Operations and Production Management 33(11/12): 124-168.

Sahir R and Brutus S (2018) A view of the role of experts in corporate consulting. Consulting Psychology Journal 70(2): 95-112.

Saint-Martin D (2004) Building the new managerialist state: Consultants and the politics of public sector reform in comparative perspective. Oxford: Oxford University Press.

Sako M (2007) Organizational diversity and institutional change. In: Aoki M, Jackson G and Miyajima H (Eds) Corporate governance in Japan. Oxford: Oxford University Press.

Samovar LA, Porter RE and McDaniel ER (2014) Intercultural communication: a reader. USA: Cenage Learning.

Schaede U (2000) Co-operative capitalism: self-regulation, trade associations and the antimonopoly law in Japan. Oxford: Oxford University Press Catalogue.

Schonfield A (1966) Modern capitalism: the changing balance of public and private power. Oxford: Oxford University Press.

Seabroke L (2014) Epistemic arbitrage: Transnational professional knowledge in action. Journal of Professions and Organization 1(1): 49-64.

Sergi V and Hallin A (2011) Thick performances, not just thick descriptions. Qualitative Research in Organizations and Management: An International Journal 6(2): 191-208.

Shigeki M (2003) Japan. In: Curnow B and Ruevid J The international guide to management consultancy. Kogan Page: London.

Source Global Research (2016) The global consulting industry in 2016. September.

Smith RC (2016) Is China the Next Japan? The Independent Review 21(2): 275-298.

Steers RM, Sanchez-Runde CJ and Nardon L (2010) Management across culturesChallenges and strategies. Cambridge: Cambridge University Press. 
Storey J (2014) New perspectives on human resource management. London: Routledge.

Sturdy AJ (2018) Promoting solutions and co-constructing problems Management consultancy and instrument constituencies? Policy and Society 37(1): 74-89.

Sturdy A, Handley K and Et al. (2009) Management consultancy: boundaries and knowledge in action. Oxford: Oxford University Press.

Sturdy A and Wright C (2008) A consulting diaspora? Enterprising selves as agents of enterprise. Organization 15(3): 427-444.

Suddaby R and Greenwood R (2001) Colonizing Knowledge Commodification as a Dynamic of Jurisdictional Expansion in Professional Service Firms. Human Relations 54(7): 933-953.

Tempel A and Walgenbach P (2007) Global standardisation? What new institutionalism and the business systems approach can learn from each other. Journal of Management Studies 44(1): 1-24.

Tether B and Tajar A (2008) Beyond industry-university links. Sourcing knowledge for innovation from consultants, private research organisations and the public science base. Research Policy 37(6-7): 1079-1095.

Tisdall P (1982) Agents of change. London: Heinemann.

Thrift N (2005) Knowing capitalism. London: Sage.

UNCTAD (2002) The tradability of consulting services and its implications for developing countries. UN: New York.

Van den Bulte C and Lilien G (2001) Medical innovation revisited. American Journal of Sociology 106(5): 1409-1435.

Vieira W (2003) Asia and Australasia, in Barry Curnow, Jonathan Reuvid (Eds) International guide to management consultancy. London: Kogan Page.

Waarts E and Van Everdingen Y (2005) The influence of national culture on the adoption status of innovations. European Management Journal 23(6): 601-610.

Westney D E (1986) Imitation and innovation the transfer of western organizational patterns to Meiji Japan. Harvard University Press.

Whitley R (2007) Business systems and organizational capabilities The institutional structuring of competitive competences. Oxford: Oxford University Press.

Witzel M (2016) A history of management thought. London and New York: Routledge Taylor and Francis Group.

Wood, P. (2003) Consultancy and innovation The business service revolution in Europe. London and New York: Routledge Taylor and Francis Group. 
Wright C and Kwon SH (2006) Business crisis and management fashion Korean companies, restructuring and consulting advice. Asia Pacific Business Review 12(3) 355 -373.

Yoda T and Harootunian H (2006) Japan After Japan Social and Cultural Life from the Recessionary 1990s to The Present. Durham and London: Duke University Press.

Yonezawa A (2011) The internationalisation of Japanese higher education. In: Marginson S, Kaur S and Sawir E Higher Education in the Asia-Pacific. London: Springer, pp. 329-343. 